\title{
State-of-the-Art Review and Critical Success Factors for Mobile Business Intelligence
}

\author{
Lee-Kwun Chan ${ }^{1}$, Hung-Khoon Tan ${ }^{1}$, Phooi-Yee Lau ${ }^{1}$ and William Yeoh ${ }^{2}$ \\ ${ }^{1}$ Faculty of Information and Communication Technology, Universiti Tunku Abdul Rahman, Malaysia \\ ${ }^{2}$ School of Information Systems, Deakin University, Australia
}

Correspondence should be addressed to: Lee-Kwun Chan; chanlk@utar.edu.my

Received 16 February 2013; Accepted 31 May 2013; Published 28 September 2013

Academic Editor: Abdallah Tubaishat

Copyright (C 2013 Lee-Kwun Chan, Hung-Khoon Tan, Phooi-Yee Lau and William Yeoh. Distributed under Creative Commons CC-BY 3.0

\begin{abstract}
Due to ubiquitous information requirements, market interest in mobile business intelligence (BI) has grown markedly. However, mobile BI market is a relatively new area that has been driven primarily by the IT industry. Yet, there is a lack of systematic study on the critical success factors for mobile BI. This research reviews the state-of-the-art of mobile BI, and explores the critical success factors based on a rigorous examination of the academic and practitioner literature. The study reveals that critical success factors of mobile BI generally fall into four key dimensions, namely security, mobile technology, system content and quality, and organisational support perspectives. The various research findings will be useful to organisations which are considering or undertaking mobile business intelligence initiatives.
\end{abstract}

Keywords: Mobile business intelligence (mobile BI), real time business intelligence, critical success factors (CSFs), service-oriented architecture (SOA).

\section{Introduction}

In recent years many enterprises have turned their efforts toward implementing Business Intelligence (BI) systems to improve their decision-making processes (Gartner 2013). A typical BI system provides functions such as reporting, multidimensional analysis, online analytical processing, ad hoc querying, data-mining and predictive modelling (Larson 2009; Sharda et al., 2010; Becerra-Fernandez et al., 2010; Turban et al., 2011). However, in an increasingly mobile world, the mobile workforce requires critical information to be accessible almost immediately ('real time') at anytime and anywhere, thus calling for a focus on BI delivery. In response to this need, interest in mobile BI by commercial markets has grown markedly recently. Mobile BI allows knowledge workers on the move to gain instant access to BI, or to so-called actionable information in various formats via handheld devices (Bates and Wall 2012). In particular, according to Gartner (2011), worldwide smartphone sales will have reached 630 million units in 2012, and are predicted to reach 1,105 million units by year 2015.Therefore, IT-literate employees not only rely on desktop computers, but they also want mobile access to corporate data. The following 
statistics show that mobile devices are now ubiquitous:

- 33 percent of business intelligence reports and dashboards will be accessed via handhelds such as smartphones and tablets computers by year 2014 (Gartner 2011).

- Around 60 percent of large corporations are likely to possess some form of mobile reporting and analytics within the next two years (BARC 2011).

- 17 percent and 35 percent of survey respondents rated Mobile BI as "critically important" and "very important" respectively (Dresner 2010).

- Nearly 33 percent of organisations plan or in the process of planning to deploy mobile BI (Gartner 2012).

The above mentioned findings indicate that mobile BI will go mainstream in the near future because there is an upward trend in the adoption of mobile platforms to achieve real-time BI. However, Gartner's (2012) survey results show that mobile BI adoption is still in its early stages, with only 20 per cent of the respondent organisations using mobile BI in 2012. So, despite the increasing smartphone sales worldwide, the adoption rate of mobile $\mathrm{BI}$ is still relatively low. Therefore, there is a burgeoning need to study which factors affect the adoption of mobile BI. A considerable and growing body of literature has been published on BI, live BI, mobile BI and real-time BI by Azvine et al., (2005), Finnie et al., (2005), Azvine et al., (2006), Azvine et al., (2007), Schneider (2006), Ranjan (2007), Sahay et al., (2008), Arnott (2008), Sajjad et al., (2009), Agrawal (2009), Mettler et al., (2009) and Castellanos et al., (2010). However, after a comprehensive review of the literature, we found very few past studies have explored the CSFs that influence the adoption of mobile BI. Therefore, the aim of this paper is to investigate relevant CSFs based on a rigorous examination of the academic and practitioner literature. The next section of this paper reviews the state-of-the-art mobile BI literature. The paper then presents the findings on CSFs, followed by the conclusions and suggestions for further research.

\section{Mobile Business Intelligence}

Mobile BI enables a mobile workforce to utilise handheld devices and gain access to real time analytics reports whenever and wherever the information is needed. Further, mobile BI encompasses additional capabilities not commonly available on desktops and laptops, for example, location awareness. It also possesses other capabilities such as tracking of near realtime data, proactive alerting to the user, and instant event-based action/function (Hagerty et al., 2012). Table 1 illustrates the applications of mobile $\mathrm{BI}$ in various industry sectors, such as healthcare, retail, sales and logistics that demand real-time decision-making for a workforce on-the-go. 
Table 1: Applications of Mobile BI by Industry Sector

\begin{tabular}{|c|c|}
\hline Industry & Application of Mobile BI \\
\hline Healthcare & $\begin{array}{l}\text { - Providing instant access by delivering actionable intelligence } \\
\text { on vital patient information, measuring and tracing medical } \\
\text { physician and organisational performance such as Key } \\
\text { Performance Indicators (KPIs) across patient healthcare, } \\
\text { providing wellness management, utilisation management, } \\
\text { profits and contract management. }\end{array}$ \\
\hline Retail & $\begin{array}{l}\text { - Monitoring of Key Performance Indicators (KPIs) such as } \\
\text { real-time store revenues, credit transactions, cash } \\
\text { transactions, staff commissions, product sales, sales margin, } \\
\text { staff turnover, product elasticity of demand and tax } \\
\text { implications. }\end{array}$ \\
\hline Human resource & $\begin{array}{l}\text { - Employees on the go can enter travelling data and their clock- } \\
\text { in and clock-out times. }\end{array}$ \\
\hline Sales & $\begin{array}{l}\text { - Salespersons can directly access organizational information, } \\
\text { be informed about new orders via a hand-held device, and } \\
\text { confirm data directly with customers on the spot. } \\
\text { - Support of other sales activities such as customer analytics, } \\
\text { proactive sales alert, real-time sales data, and performance } \\
\text { reporting.. }\end{array}$ \\
\hline $\begin{array}{l}\text { Executive / } \\
\text { Senior } \\
\text { Management }\end{array}$ & $\begin{array}{l}\text { - Monitoring of real-time organisational Key Performance } \\
\text { Indicator (KPI's), access to data on demand anywhere. } \\
\text { - Performing decision-making on-the-go. }\end{array}$ \\
\hline $\begin{array}{l}\text { Field Service } \\
\text { Personnel }\end{array}$ & - Allowing proactive service alerts. \\
\hline Insurance & $\begin{array}{l}\text { - Agents, policyholders and insurance company agents can } \\
\text { interact with functions which are provided by their insurers. }\end{array}$ \\
\hline $\begin{array}{l}\text { Flight } \\
\text { Management }\end{array}$ & - Identifying issues related to flight network. \\
\hline Logistics & - Managing real-time package flow technologies. \\
\hline
\end{tabular}

A review of $\mathrm{BI}$ architecture literature shows that modern BI architectures are multi-layered, service-oriented and loosely-coupled. A presentation layer, an application layer and a data layer form the basis of contemporary BI architecture. BI architecture built on Service-oriented Architecture (SOA) principles can separate implementation components from the underlying infrastructure. Modern BI architecture supports security, availability, capacity, inter-changeability, resiliency and flexibility with this separation (IBM Global Technology Services 2007; Ashrafi et al., 2009; Dinter and Stroh 2009; Dennis et al., 2010; Hirschheim et al., 2010). Nevertheless, the SOA-based BI architecture still does not overcome the various issues faced by mobile $\mathrm{BI}$, such as security, mobile device interface issues during the transfer of huge volumes of data, and network connectivity, consistency and high-user expectations. Interestingly, based on the analysis of various architectures from major BI vendors (including Gordon et al., 2006; Wu et al., 2007; MicroStrategy 2007; Oracle 2012; IBM Cognos 2010; SAP 2012), we found that mobile BI does not differ significantly from traditional BI architecture, except that mobile solutions are integrated into existing BI architecture on the presentation layer.

Real-time requirements present a new set of challenges to mobile BI vendors because concurrent updates to active dashboards are required which lead to changes on dashboard designs in the user interface (Becerra-Fernandez et al., 2010; Turban et al., 2011). Some studies have examined the challenges and trends on mobile BI (Airinei and Homocianu 2010; Stipic and Bronzin 
2011). Specifically, Stipic and Bronzin (2011) highlighted the four main challenging areas for mobile BI: hardware and communication devices, user experience, software, and architecture. Airinei and Homocianu (2010) found that the challenges of mobile BI are mainly caused by the physical limitations of mobile devices such as poor display resolution, tiny visual screen size, low memory and low processing power, as well as the architecture of a mobile operating system. In summary, the key issues associated with mobile $\mathrm{BI}$ as defined by the following authors: Panian (2008); Airinei and Homocianu (2010); Stipic and Bronzin (2011); and Bates and Harris (2012) are listed below:

Security: The use of applications or "apps" presents new security challenges in terms of data access, data transmission, and data storage that must be addressed when deploying a mobile BI solution. Most mobile BI users raise concerns on how devices and data transmission will be secured, and how users will be authorised and authenticated. The use of mobile BI presents higher security risks on data and at the device level than traditional BI. In addition, the loss of devices could subsequently lead to unauthorised access to sensitive corporate data.

Mobile Device Interface: The requirements for desktops, tablets and smartphones are different due to limitations of screen size and resolution. However, desktop experience cannot be applied on mobile devices. An entire dashboard can be displayed at once on desktops and tablets but that cannot be achieved on smart phones.

Transfer Huge Volume of Data: The effectiveness of Mobile BI delivery is affected when a huge volume of data is being transferred into the system, therefore, only certain analytical capabilities can be provided on mobile BI.

Unstable Network Connectivity: Stable access to the Internet is not promised by Internet service providers, or telecommunications service providers, because network connectivity depends on weather, geographic location, as well as other factors.

Inconsistency: The reports and dashboards displayed on desktop and mobile devices are different due to screen size limitation. As it is extremely critical to ensure the same report content is accessed from different devices, re-creation of reports for mobile platforms should be avoided.

High User Expectation: Users always assume mobile BI is like traditional BI implementation, which may lead to user dissatisfaction and disappointment because the features offered by mobile BI are often not as rich as that experienced on desktops or laptops.

Despite the various issues and complexities in implementing mobile BI, there has been little academic research on CSFs for mobile BI. The increasing rate of adoption of mobile BI and the scarcity of academic research justify the need for a study into the factors required for successful mobile BI uptake, beyond the challenges highlighted by previous studies.

\section{CSFs Findings}

The Information System (IS) literature contains a number of empirical studies about the CSFs for business intelligence success. However, to date, there is little academic research that considers specific CSFs for mobile BI. Although there is considerable practitioner wisdom on the critical factors for mobile BI use, it is based on their personal experience or on anecdotal evidence from a limited number of organisations.

This study finds there is little academic research into the CSFs that affect mobile BI from managerial and technological perspectives. Drawing upon literature from academia and field practitioners, a total of sixteen factors have been identified and grouped into four main dimensions, namely, security, mobile technology, system content and quality, and organisational support. 
Table 2: Critical Success Factors for Mobile BI

\begin{tabular}{|c|c|c|c|}
\hline Dimension & CSF(s) & Definition & References \\
\hline \multirow[t]{3}{*}{ Security } & Data security & $\begin{array}{l}\text { The capability to ensure the system is protected } \\
\text { from data loss and cached data security on the } \\
\text { mobile device. }\end{array}$ & $\begin{array}{l}\text { Deepak et al., (2012), Kuntze } \\
\text { et al., (2010), Panian (2008) }\end{array}$ \\
\hline & Device security & $\begin{array}{l}\text { The capability to ensure the system is protected } \\
\text { from the loss of the mobile device itself. }\end{array}$ & $\begin{array}{l}\text { Deepak et al., (2012), Kuntze } \\
\text { et al., (2010), Panian (2008) }\end{array}$ \\
\hline & Authentication & $\begin{array}{l}\text { The capability to ensure the system is protected } \\
\text { from unauthorised access to information. }\end{array}$ & $\begin{array}{l}\text { Deepak et al., (2012), Kuntze } \\
\text { et al., (2010), Panian (2008) }\end{array}$ \\
\hline \multirow[t]{8}{*}{$\begin{array}{l}\text { Mobile } \\
\text { technology }\end{array}$} & $\begin{array}{l}\text { Device } \\
\text { independence }\end{array}$ & $\begin{array}{l}\text { The capability to support and deliver BI content } \\
\text { regardless of the platform and device. }\end{array}$ & $\begin{array}{l}\text { Sajjad et al., (2009), Airinei } \\
\text { and Homocianu (2010), } \\
\text { Stipic and Bronzin (2011) }\end{array}$ \\
\hline & Usability & $\begin{array}{l}\text { The capability to provide larger and intuitive } \\
\text { handheld interface for visualising key performance } \\
\text { indicators and drilling-down into detailed metrics } \\
\text { with a broad range of formats. }\end{array}$ & $\begin{array}{l}\text { Ashrafi et al.,(2009), } \\
\text { O'Brien et al., (2007), Meier } \\
(2009) \text {, Deepak et al., } \\
(2012) \text {, Stipic and Bronzin } \\
(2011)\end{array}$ \\
\hline & Accessibility & $\begin{array}{l}\text { The extent to which a mobile BI system has to } \\
\text { operate on a } 24 \times 7 \text { basis with the exception of } \\
\text { scheduled maintenance. }\end{array}$ & $\begin{array}{l}\text { Dennis et al., (2010), } \\
\text { O'Brien et al., (2007), }\end{array}$ \\
\hline & $\begin{array}{l}\text { Network } \\
\text { connectivity }\end{array}$ & $\begin{array}{l}\text { The stable connection of mobile devices to the } \\
\text { wireless network. }\end{array}$ & $\begin{array}{l}\text { Deepak et al., }(2012), \\
\text { Castellanos et al., } \\
\text { (2010), } \\
\text { Airinei et al., (2010) }\end{array}$ \\
\hline & Flexibility & $\begin{array}{l}\text { The ease of changing the previous design to } \\
\text { support for online and offline modes. }\end{array}$ & $\begin{array}{l}\text { Shim et al., (2008), Ajain et } \\
\text { al., (2011) }\end{array}$ \\
\hline & Consistency & $\begin{array}{l}\text { The capability to enable reports and dashboards to } \\
\text { be presented consistently in desktops and mobile } \\
\text { versions. }\end{array}$ & Hagerty et al., (2012) \\
\hline & Reusability & $\begin{array}{l}\text { The capability of the BI architecture design that } \\
\text { allows application to be re-applied to other } \\
\text { solutions }\end{array}$ & $\begin{array}{l}\text { Meier (2009),Shim et al., } \\
(2008)\end{array}$ \\
\hline & Functionality & $\begin{array}{l}\text { To allow users to do content search, drill-down, } \\
\text { filter, sort and explore the insights when and } \\
\text { wherever they are, without having to wait for re- } \\
\text { creation of a new report or a dashboard. }\end{array}$ & Meier (2009) \\
\hline \multirow[t]{3}{*}{$\begin{array}{l}\text { System content } \\
\text { and quality }\end{array}$} & $\begin{array}{l}\text { Support of } \\
\text { interactive } \\
\text { conferencing }\end{array}$ & $\begin{array}{l}\text { The ability of the mobile BI to enable users to } \\
\text { share reports, walk through data live in real-time, } \\
\text { carry out interactive conference among recipients } \\
\text { and allow commenting. }\end{array}$ & Hagerty et al., (2012) \\
\hline & Customisation & $\begin{array}{l}\text { The capability to tailor BI content to specific user } \\
\text { profile and not to rollout the same content to all } \\
\text { users. }\end{array}$ & Russom (2007) \\
\hline & $\begin{array}{l}\text { Right-time } \\
\text { report }\end{array}$ & $\begin{array}{l}\text { The ability to deliver quick, concise and meaningful } \\
\text { reports to specific user-groups as and when } \\
\text { required. }\end{array}$ & Watson et al., (2006) \\
\hline \multirow[t]{2}{*}{$\begin{array}{l}\text { Organisati-onal } \\
\text { support }\end{array}$} & $\begin{array}{l}\text { Management } \\
\text { support }\end{array}$ & $\begin{array}{l}\text { Organisations should articulate a clearly defined } \\
\text { set of strategies to enable an effective delivery of } \\
\text { Mobile BI. }\end{array}$ & McCalister (2012) \\
\hline & $\begin{array}{l}\text { Skill and } \\
\text { knowledge }\end{array}$ & $\begin{array}{l}\text { Organisations should provide adequate trainings } \\
\text { on skills and knowledge to mobile users. }\end{array}$ & $\begin{array}{l}\text { McCalister (2012), Arnott } \\
\text { (2008), Wixom and Watson } \\
(2001)\end{array}$ \\
\hline
\end{tabular}

Table 2 above presents the findings of the research and outlines the CSFs for mobile BI. The following section describes each of the critical factors in detail under the respective dimension of interest.

\section{Security Dimension}

Data Security: Mobile BI users are exposed to new risks and security holes have been reported, even with the implementation of 
complicated security mechanisms (Kuntze et al., 2010). Security of wireless data transmission from BI server to mobile devices is a major concern, especially when the users are on a public network, because intruders could easily attack the Virtual Private Network (VPN) via interconnected nodes (Deepak et al., 2012). In addition, the confidential information of mobile users can be tracked through mobile devices; therefore, no data should be stored on a mobile device.

Device Security: Due to its physical size, a mobile device could be misplaced or lost easily. It is extremely critical to consider security measures on how to protect organisations from the loss of the mobile device itself.

Authentication: Different users may be given access to different subsets of data and reports. For example, some users may be able to drill down to detailed information in a report whereas others cannot. Unauthorized users should be prohibited from accessing other users' critical information (Deepak et al., 2012). The system must be protected from unauthorised access to information, especially when using public wireless networks.

\section{Mobile Technology Dimension}

Device Independence: The success or failure of a mobile BI project depends, to some extent, on the delivery platform, which includes the device specifications and the operating system. All BI users should be able to access information in a consistent manner, however, regardless of the type of device and the platform.

Usability: Human interface with mobile devices through screens and keyboards is always restricted by size constraints (Deepak et al., 2012). Limitations in mobile devices such as screen size, poor visual screen resolution, and cumbersome input mechanisms, have posed new interfacing challenges with mobile BI where mobile client software needs to optimise the delivery of report content in an easy-tounderstand format based on the size of the screen. In addition, users should be given a path to present effective feedback or control over communications (O'Brien et al., 2007).

Accessibility: Easy executive access to information at a fast data transfer speed is essential to provide a clear view of all business-critical data, both at the executives' desks and on mobile devices.

Network Connectivity: Ideally, mobile devices should be connected constantly to a stable wireless network, however, that is not always the case. Wireless technologies are usually available only when users are within a certain range of telecommunication towers (Deepak et al., 2012). Therefore, an auto-synchronisation facility should be incorporated into mobile BI when a connection is re-established after being disconnected.

Flexibility: In certain scenarios, most notably during a flight, users might need to disconnect from the BI server. Therefore, flexibility of both online as well as offline access modes is essential so that users can still perform certain tasks, for example, read a pre-loaded report when the network is disabled (Shim et al., 2008; Ajain et al., 2011).

Consistency: Data inconsistency leads to poor decision-making and poor outcomes as a result (Hagerty et al., 2012). Therefore, mobile BI solutions should be able to present all critical information in a limited mobile display space with similar content to its desktop version, but without suffering any loss of information.

Reusability: Shim et al., (2008) defined reusability as the degree of re-application of an existing solution to other applications. A dashboard or report template should be designed and built only once, but be accessible on all other relevant devices and solutions.

Functionality: BI users on the move do not have the luxury of time to go through the data to find the information they need. Therefore, mobile BI should provide effective search and browsing tools that 
will enable users to get required information in a short period. Thus, the capabilities to drill-down, filter and perform fast content searches are extremely critical for mobile BI users.

\section{System Content and Quality Dimension}

Support of Interactive Conferencing: Since mobile applications are naturally a social platform to share and discuss ideas and information, mobile BI should enable users to walk through data live and allow interactive comments over the course of a virtual meeting.

Customisation: User groups may need to have access to different content and access levels. Therefore, BI content such as reports and dashboards must be able to be customized to respond to the needs of different departments (e.g., human resources, production, Information Technology departments, etc.), or user profiles (e.g., executives, sales, chairman, department heads, etc.) based on their role and responsibility in an organisation.

Right-Time Report: With time pressures from accelerated markets, analytics reports should be available on demand. For example, right-time mobile BI would refresh every 30 minutes if there is a need to report every 30 minutes.

\section{Organisational Support Dimension}

Management Support: As BI initiatives are driven by business, a strategic long-term organisation vision is essential to direct mobile BI implementation in the long run. Successful deployment of mobile BI requires huge alignment and support from management as well as the allocation of the devoted resources. Therefore, initially, an organisation should clearly define a set of strategies to enable effective delivery of mobile BI.

Skill and Knowledge: The level of skills and knowledge of BI users is believed to play a significant role in the success of mobile BI. Even mobile users who have past experience with other mobile devices could encounter difficulties switching from their existing technological frames due to the differences in features, as well as the sequences to achieve a task. Hence, it is important for an organisation to equip all mobile workers across the organisation with adequate skills and knowledge to use mobile BI (McCalister 2012; Arnott 2008; Wixom and Watson 2001).

In short, the findings show that there is a combination of multi-dimensional CSFs peculiar to successful mobile BI implementation. More importantly, this study has narrowed the research focus through the identification of a set of CSFs as presented.

\section{Contributions}

This study aims to review state-of-the-art mobile BI, and explore the CSFs based on a rigorous examination of the academic and practitioner literature. Therefore, this study contributes to filling the research gap between academics and practitioners. This paper has reported the exploratory results on CSFs that could influence mobile BI success. To the best of our knowledge, this study is the first attempt to explore the CSFs which influence the use of mobile BI in organisations. It shows a clear trend towards multi-dimensional challenges in implementing mobile BI.

Amongst the findings, the research indicates that CSFs exist in various dimensions, namely, security, mobile technology, system content and quality, and organisational support perspectives. Although these CSFs require further research to test and confirm their robustness in theory and practice, they constitute an important development in knowledge about CSFs impacting mobile BI, and contribute to a better understanding of how mobile BI implementation can be improved. The various research findings will be useful to organisations which are planning, assessing, or undertaking mobile business intelligence initiatives.

\section{Conclusion}

This study represents the first attempt to explore how a set of CSFs influence the 
adoption of mobile BI in organisations. The research findings would be useful to organisations which are planning or undertaking mobile BI initiatives. The study on mobile BI CSFs is not only of theoretical, but of practical significance. This paper highlights four important dimensions for managers who intend to initiate mobile $\mathrm{BI}$, and provides $\mathrm{BI}$ stakeholders and practitioners with the essential determinants to achieve successful implementation of mobile BI. The exploratory research provides a fundamental reference point for further empirical research, such as questionnaire surveys, interviews and case studies, to shed light on where and how the CSFs influence the success of mobile BI.

\section{Acknowledgment}

An earlier version of this article appeared in the Proceedings of the 20th IBIMA International Business Information Management Conference 25-26 March 2013 in Kuala Lumpur. We would like to thank the anonymous reviewers for their valuable comments.

\section{References}

Agrawal, D. (2009). "The Reality of RealTime Business Intelligence," Intelligence, Springer Berlin Heidelberg, 75-88.

Airinei, D. \& Homocianu, D. (2010). "The Mobile Business Intelligence Challenge," Economy Informatics, 10(1), 5-12.

AJain, H., Sinha, A. P. \& Vitharana, P. (2011). DESRIST 2011, LNCS 6629, Springer-Verlag Berlin Heidelberg, 306-320.

Arnott, D. (2008). Success Factors for Data Warehouse and Business Intelligence Systems.

Ashrafi, N. \& Ashrafi, H. (2009). Objectoriented Systems Analysis and Design, Pearson Education Inc.

Azvine, B., Cui, Z. \& Nauck, D. D. (2005). "Towards Real-Time Business Intelligence," BT Technology Journal, Kluwer Academic Publishers. 23(3), 214-225.
Azvine, B., Cui, Z., Majeed, B. \& Spott, M. (2007). "Operational Risk Management with Real-Time Business Intelligence," BT Technology Journal, 25, 154-167.

Azvine, B., Cui, Z., Nauck, D. D. \& Majeed, B. (2006). "Real Time Business Intelligence for the Adaptive Enterprise," The 8th IEEE International Conference on ECommerce Technology and The 3rd IEEE International Conference on Enterprise Computing ECommerce and EServices CECEEE06, IEEE,14(24), 29-29.

BARC (2011). The BI Survey 10. Business Application Research Center, [Online], [Retrieved December 10, 2012], http://www.bisurvey.com/index.php.

Bates, C. \& Wall, C. (2012). "Top Six BI Trends for 2012," [Online], [Retrieved December 1, 2012], http://www.cio.com.au/article/421700/to p_six_bi_trends_2012.

Becerra-Fernandez, I. \& Sabherwal, R. (2010). 'Business Intelligence: Practices, Technologies, and Management,' John Wiley \& Sons Inc.

Castellanos, M., Dayal, U. \& Hsu, M. (2010). "Live Business Intelligence for the RealTime Enterprise," Springer 6462, 325336.

Deepak, G. \& Pradeep, B. S. (2012). "Challenging Issues and Limitations of Mobile Computing," International Journal of Computer Techology \& Applications, Vol 3 (1), 177-181.

Dennis, A., Wixom, B. H. \& Roth, R. M. (2010). System Analysis and Design, 4rd. John Wiley \& Sons, Inc.

Dinter, B. \& Stroh, F. (2009). "Design Factors for Service-Oriented Architecture Applied to Analytical Information Systems: An Explorative Analysis," In 17th European Conference on Information Systems (Newell S, Whitley EA, Pouloudi N, Wareham J, Mathiassen L eds.), Verona, Italy, ISBN 97888-6129-391-5, 2687-2698. 
Dresner, H. (2010). 'Mobile Business Intelligence Market Study,' [Online], [Retrieved December 1, 2012], www.mobile-bi.study.com.

Finnie, G. \& Barker, J. (2005). "Real-Time Business Intelligence in Multi-Agent Adaptive Supply Networks," 2005 IEEE International Conference on eTechnology eCommerce and eService, IEEE, 218221.

Gartner (2011). 'Gartner Predicts 2011: New Relationships Will Change BI and Analytics,'

Gartner (2012). "Magic Quadrant for Business Intelligence Platforms," [Online], [Retrieved December 10, 2012],http://www.gartner.com/technolog y/reprints.do?id=1-

1982NPD\&ct=120208\&st=sb.

Gartner (2013). "Gartner Says Worldwide Business Intelligence Software Revenue to Grow 7 Percent in 2013," [Retrieved March 01 ,

2013],http://www.gartner.com/newsroom /id/2340216.

Gordon, S., Grigg, R. \& Horne, M. (2006). "Service-Oriented Business Intelligence," Microsoft MSDN The Architecture Journal. [Online], [Retrieved December 1, 2012], http://msdn.microsoft.com/en-

us/library/bb245659.aspx.

Hagerty, J., Sallam, R. L. \& Richardson, J. (2012). "Magic Quadrant for Business Intelligence Platforms," [Online], [Retrieved August 5, 2012],http://www.gartner.com/technolog y/reprints.do?id=1-

1982NPD\&ct=120208\&st=sb.

Hirschheim, R., Welke, R. \& Schwarz, A. (2010). "Service-Oriented Architecture: Myths, Realities, and a Maturity Model," MIS Quarterly, 9(1), 37-48.

IBM Cognos (2010). "IBM Cognos Business Intelligence V10.1 Handbook," [Online], [Retrieved December 10, 2012], http://www.ibm.com/redbooks.
IBM Global Technology Services (2007). "Infrastructure Considerations for ServiceOriented Architecture," White Paper.

Kuntze, R., Sohr, M. \& Diederich, S. (2010). 'Detken: Secure Mobile Business Information Processing,' In IEEE/IFIP International Symposium on Trusted Computing and Communication (TrustCom), IEEE/IFIP EUC (Vol. 11, p. 13).

Larson, B. (2009). Delivering Business Intelligence with Microsoft SQL Server 2008, McGraw-Hill/Osborne.

McCalister, A. (2012). "The Top Factors That Affect the Commercial Success of High-Growth Companies," Business Intelligence Journal, January, 2012 Vol.5 No.1.

Meier, J. D. (2009). 'A Language for Software Architecture,' The Architecture Journal TechEd Special Edition. Mircosoft. [Online], [Retrieved Feb 11, 2012], http://www.architecturejournal.net.

Mettler, T. \& Vimarlund, V. (2009). "Understanding Business Intelligence in the Context of Healthcare," Health Informatics Journal, 15(3), 254-264.

Microstrategy (2007). "Enterprise Business Intelligence, Improving Corporate Performance through Integrated Reporting, Analysis, and Monitoring," White Paper.

O'Brien, L., Merson, P. \& Bass, L. (2007). "Quality Attributes for Service-Oriented Architectures," International Workshop on Systems Development in SOA Environments SDSOA07 ICSE Workshops 2007.p. 3-3. IEEE Computer Society.

Oracle Corporation (2012). "Oracle ${ }^{\circledR}$ Fusion Middleware System Administrator's Guide for Oracle Business Intelligence Enterprise Edition 11g Release 1 (11.1.1)," [Online], [Retrieved December 10, 2012],http://docs.oracle.com/cd/E17904_ 01/bi.1111/e10541/getting_started.htm\#C HDJICDD. 
Panian, Z. (2008). "How to Make Business Intelligence Actionable through ServiceOriented Architectures," WSEAS Transactions on Business and Economics, 5(5), 210-221.

Ranjan, J. (2007). "Need for Real Time Business Intelligence," Management Change, Inderscience.

Russom, P. (2007). Business Intelligence Solutions for SAP, The Data Warehousing Institute (TDWI) Research, Fourth Quarter 2007 TDWI Best Practices Report.

Sahay, B. S. \& Ranjan, J. (2008). "Real Time Business Intelligence in Supply Chain Analytics. Information Management Computer Security," Emerald insight, 16(1), 28-48.

Sajjad, B., Mir, A., Khawar, A., Bashir. F. \& Tariq, A. (2009). "An Open Source Service Oriented Mobile Business Intelligence Tool (MBIT)," IEEE, 978-1-4244-4609-4.

SAP (2012). "SAP BusinessObjects BI 4.0 Now Delivers Native Support for Mobile Devices," [Online], [Retrieved November 5, 2012],http://scn.sap.com/community/mo bile/businessobjects/blog/2012/05.

Schneider, D. (2006). "Practical Considerations for Real-Time Business Intelligence," Intelligence, 1 - 3.

Sharda, R., Aronson, J. E., King, D., Delen, D., Turban, E. \& Liang, T. (2010). Decision Support and Business Intelligence Systems, 9th Ed., Prentice-Hall.

Shim, B., Choue, S., Kim, S. \& Park, S. (2008). A Design Quality Model for ServiceOriented Architecture. 15th Asia-Pacific Software Engineering Conference. IEEE.

Stipic, A. \& Bronzin, T. (2011). "Mobile BI: The Past, the Present and the Future," Proceedings of the 34th International Convention (MIPRO 2011), ISBN: 978-14577-0996-8, IEEE, 23-27 May 2011, Opatija, Croatia, 1560-1564.
Turban, E., Shard, R., Aronson, J. E. \& King, D. (2011). 'Business Intelligence: A Managerial Approach,' Second Edition, Pearson Prentice Hall.

Watson, H. J., Wixom, B. H., Hoffer, J. A., Anderson-Lehman, R. \& Reynolds, A. M. (2006). "Real-Time Business Intelligence: Best Practices at Continental Airlines," Information Systems Management, 23(1), 718.

Wixom, B. H. \& Watson, H. J. (2001). "An Empirical Investigation of the Factors Affecting Data Warehousing Success," MIS Quarterly 25, 17-41.

Wu, L., Barash, G. \& Bartolini, C. (2007). "A Service-oriented Architecture for Business Intelligence," Proceedings of the IEEE International Conference on ServiceOriented Computing and Applications (SOCA '07), 279-285. 